\title{
FILLED PAUSES IN HUNGARIAN: THEIR PHONETIC FORM AND FUNCTION*
}

\section{VIKTÓRIA HORVÁTH}

\author{
Phonetics Department, Research Institute for Linguistics \\ Hungarian Academy of Sciences \\ Benczúr u. 33. \\ H-1068 Budapest \\ Hungary \\ horviki@nytud.hu
}

\begin{abstract}
Filled pauses are natural occurrences in spontaneous speech and they may turn up at any level of the speech planning process and in a number of functions. The aim of this paper is to find out whether the diverse functions of filled pauses correlate with diverse articulations resulting in diverse acoustic structures. Spontaneous narratives are used as research material. The duration of the filled pauses and the frequency values of their first two formants are analyzed. The most frequent form, schwa, shows function-dependent realizations as confirmed by the durational values and by the second formant values of these vowellike sounds.
\end{abstract}

Keywords: filled pause, silent pause, speech planning, function-dependent realization, speech error

\section{Introduction}

Spontaneous speech is usually rich in disfluency due to the simultaneous operations of speech planning and articulation. Ever since the 1950s, speech errors and disfluencies have been studied as a window into the processes of speech planning (e.g., Goldman-Eisler 1958; Fromkin 1973; Levelt 1989; Shriberg 2001). Disfluencies usually reveal speech planning or execution problems, have a function in self-monitoring, and indicate

* This research was supported by the Hungarian National Scientific Research Fund (OTKA), project No. 78315 . 
that the speaker does not know how to continue or is unable to recall a particular word. They also serve as floor-holders when a speaker needs some additional time to plan the utterance but does not want to cede the floor to the interlocutor (Maclay-Osgood 1959; Livant 1963; Lallgee-Cook 1969). They have a communicative function of helping people manage turn-taking, and mark the speakers' mental state (Clark 1994; Brennan-Williams 1995; Clark-Fox Tree 2002). Many studies have been done on the factors that might affect fluency rates including the speaker's age, gender, difficulty of topic domain, length of the utterance, relationship between speakers, etc. (Shriberg 1996; Yaruss et al. 1999; Bortfeld et al. 2001).

Silent pauses and filled pauses are among the most frequent disfluency phenomena that occur in spontaneous speech. They have been investigated since the 1950s (Mahl 1956; Goldman-Eisler 1958; MaclayOsgood 1959). A silent pause may be considered as disfluency when it does not serve for breathing or for marking a boundary and it does not occur in a rhetoric function, either. Duez (1982) classifies silent pauses into various categories, although she admits that it is almost impossible to do so on the basis of the data alone (cf. Boulton 2006).

There is no general agreement about the terms and their contents concerning filled pauses in the literature. They are variously labeled as filled pauses, hesitations, hesitation pauses or fillers/filler words (cf. Cook 1971; Ruder-Jensen 1972; Eklund 2001; Clark-Fox Tree 2002; CorleyHartsuiker 2003; House 2003). On the other hand, some researchers use hesitation phenomena as an umbrella term covering a variety of surface disfluencies like prolongation, word or syllable repetition as well as lexical search (cf. Hokkanen 2001).

Speakers spend the duration of filled pauses producing speech sounds whose articulation requires the least amount of energy. The most frequent forms in English are um, uh and er (Levelt 1989; Clark-Fox Tree 2002). Filled pauses are natural occurrences in spontaneous speech and they may turn up at any level of the speech planning process and in a number of functions. They may occur during conceptual planning or grammatical or phonological encoding, and also during lexical selection (Levelt 1989; Gósy 2002). Filled pauses provide time to surmount difficulties in speech planning or signal ongoing selection processes (Beattie-Butterwoth 1979). Furthermore, speakers may need to produce filled pauses because of their uncertainty concerning either the topic of the conversation or the selection of words or grammatical structures. Filled pauses 
also occur in the vicinity of various other speech errors. In the latter case, they mark the speaker's problem and provide time for the correction process. Filled pauses also play an important role in conversations where they indicate the participant's intention to speak (Local 2004). In this case, they frequently occur turn-initially. Filled pauses at the end of turns have two main functions. They either signal that the speaker needs time for speech planning processes for various reasons. In this case, the speaker wants to continue speaking; in other words, s/he wants to keep the floor. Or, on the contrary and frequently again, the speaker wants to inform the interlocutor that $\mathrm{s} /$ he is about to finish speaking (MaclayOsgood 1959; Bortfeld et al. 2001). The context might provide clues for distinguishing these two functions of turn-final fillers.

Filled pauses as well as silent ones are also important for speech perception - they provide time for the listener's comprehension processes (Gósy 2000; Fox Tree 2002; Corley-Hartsuiker 2003).

There is a debate in the literature concerning whether the filled pauses uh or um are real lexical items in English. These items are supposed by some authors to be conventional English words that speakers plan for, formulate, and produce just as they would do with any other word (Clark-Fox Tree 2002). Filled pauses have their own meanings-utterances including $u m$ or $u h$ do not mean quite the same thing as the corresponding utterances without them. In addition, speech perception deals with um and $u h$ in the same way as it treats other words. Other researchers, however, do not share this opinion and do not consider um and $u h$ to be words; moreover, they consider them to be mere noises (Lickley 1995; Lickley-Bard 1996).

A number of factors influence the frequency of filled pauses in spontaneous speech: the age and mental state of the speaker, the topic of conversation, the type of the text, the syntactic structure involved, the length of the utterance, etc. (Cook 1971; Ruder-Jensen 1972; Shriberg 1996; Yaruss et al. 1999; Merlo-Mansur 2004; Bortfeld et al. 2001; Watanabe et al. 2008).

Several former investigations analyzed function-dependent realizations of hesitation phenomena in English. Mahl (1956) divided the types of hesitations, according to their functions, into two groups. Investigations showed that um occurs at the beginning of the utterance in general-speakers produce this form during the planning of larger units. In contradistinction to $u m$, uh is produced during lexical selection (Shriberg 1996). Um is generally used in the case of larger speech planning processes 
(Clark-Fox Tree 2002). Silent pauses after um hesitations are longer than those after $u h$ hesitations. In addition, um informs the listener that the speaker has a problem in speech planning and the utterance will not be continued according to the listener's expectation (Corley-Stewart 2008). There is another form of English hesitation, er, whose occurrence is claimed to depend on function. Speakers use er as an editing term in $92 \%$ of all covert repairs, whereas only $6 \%$ of fresh starts are introduced by a filled pause of the er type (Levelt 1989).

A similar function-dependent distribution of Japanese hesitation phenomena could not be established, although some tendencies could be found toward some division of functions (Watanabe et al. 2008). Speakers of Japanese prefer the hesitation forms ano and $e$ in cases where they would not produce the form ma.

Filled pauses constitute one of the most frequent types of disfluency in Hungarian spontaneous speech, too (Gósy 2003; Markó 2004; Horváth 2004; Bóna 2006). They invariably indicate some disharmony between planning and execution (Gósy 2003). The terms filled pause and hesitation are used as synonyms in the Hungarian literature. There are authors who consider fillers or filler words functionally also hesitations (Eklund 2001). In this paper, however, the word filled pause will be used for phenomena when the speaker suspends his/her speech and produces a sound or sound sequence that has no meaning in the language.

Filled pauses are realized in various phonetic forms in Hungarian. Some of them consist of a single speech sound while others comprise two or more speech sounds. According to recent investigations, the most frequent form is a schwa-like vowel (Gósy 2002). This neutral vowel form requires the least articulatory effort. Although filled pause is the most frequent type of disfluency, there has been no systematic investigation of its phonetic realization and function in Hungarian so far.

The topic of the present paper is a functional and acoustic-phonetic analysis of filled pauses in Hungarian spontaneous speech. The goal of the research was to find out whether the diverse functions of these filled pauses are accompanied by different articulation gestures and yield different acoustic structures. Our hypothesis is that filled pauses in spontaneous speech exhibit diverse acoustic structures depending on their functions. 


\section{Method, material, subjects}

Spontaneous narratives from the BEA Hungarian Spontaneous Speech Corpus (Gósy 2008) were used for the present research. The speakers were all native Hungarian-speaking subjects, 10 males (ages ranged from 29 to 41) and 10 females (ages ranged from 20 to 49). The topics of the narratives were the subjects' work, family and hobbies on the one hand, and an up-to-date, interesting topic relevant to the subjects' age and gender on the other.

The recorded narratives, with a total duration of 177 minutes, were submitted to annotation and acoustic phonetic analysis by Praat 4.5 (Boersma-Weenink 2005, cf. Figure 1).

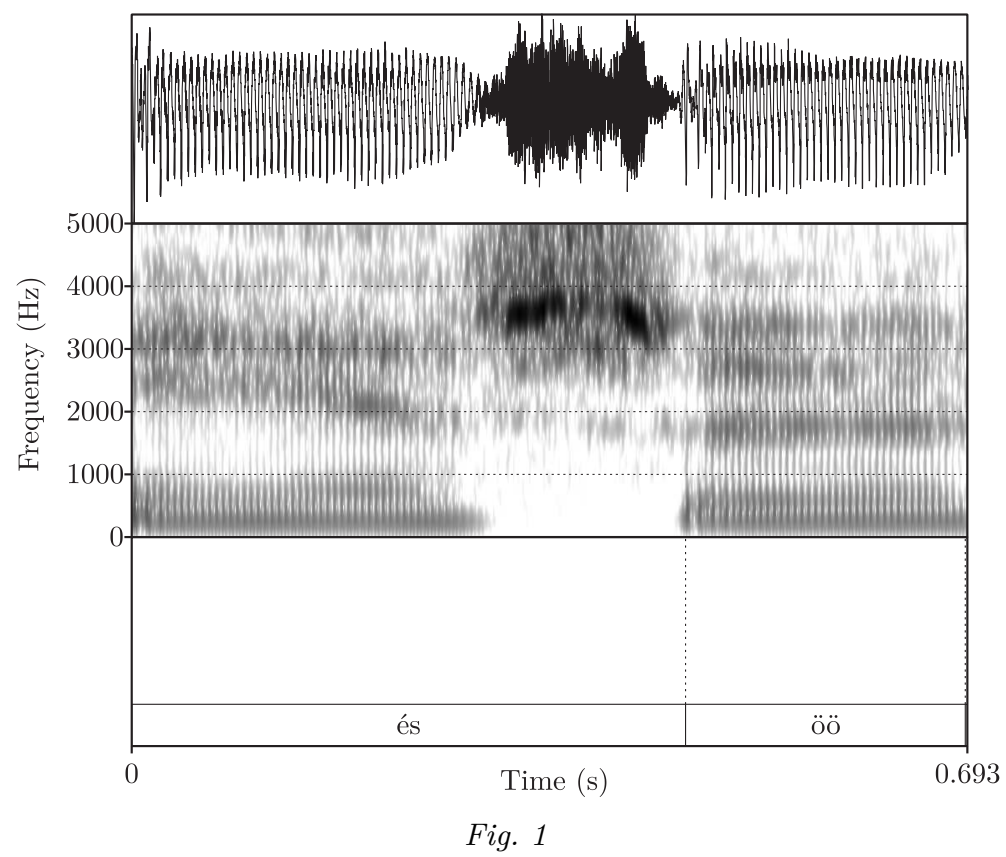

The method of annotation using Praat 4.5

The total duration of the silent and filled pauses as well as the frequency values of the first two formants of schwa-realizations were analyzed. The formant values were measured at the midpoint of total vowel duration (by automated Praat script) and were controlled manually. The silent pauses occurring in the vicinity of filled pauses and filled pauses themselves were 
annotated manually using Praat software (see above). The duration of silent pauses was defined on the basis of the initial and final points of the labels. None of them was part of a consonant. Silent pauses in utterance initial position were ignored. The values of the pauses were obtained automatically (by Praat script). The shortest duration of silent pauses that were taken into consideration was $30 \mathrm{~ms}$ (independently of whether they served for breathing or for any other function). However, there was no durational criterion in the case of filled pauses.

The actual function of the filled pauses was defined on the basis of the context in each case. To test statistical significance adequate tests were performed using SPSS 13.0 (t-tests, analysis of variance).

\section{Results}

The material contained 666 filled pauses (306 from males and 360 from females). Speakers produced 3.82 filled pauses per minute on average. However, large individual differences were found among speakers (min.: 0.8, max.: 9.5). There was no significant difference between males and females concerning the occurrence of filled pauses (Figure 2). 3.78 filled pauses per minute occurred in the males' speech on average and 3.86 such phenomena in the female speakers' corpus.

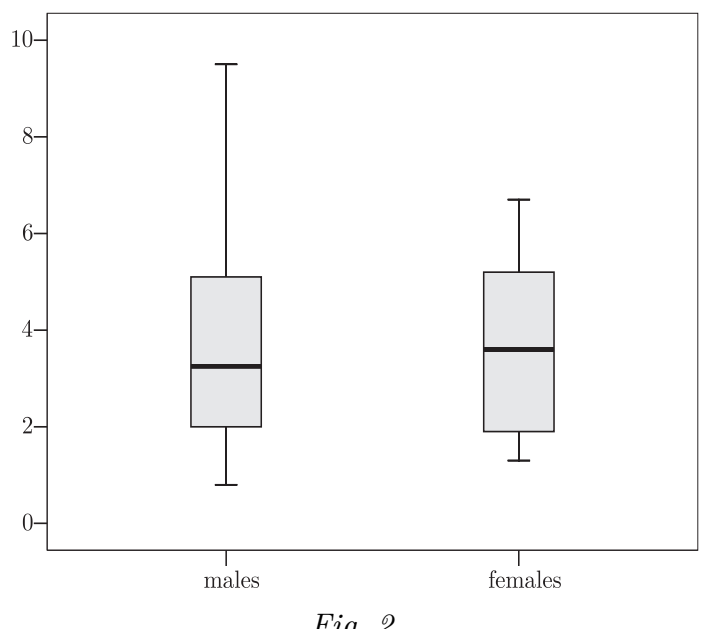

The occurrence of filled pauses per minute 
The forms of filled pauses in our material show eight different types. They consist either of one speech sound or of two or three speech sounds. The single speech sound is a netural vowel or a diphthong-like combination of two vowels $([\ni, \varepsilon ə])$ or a bilabial nasal consonant $[\mathrm{m}]$. Filled pauses consisting of several speech sounds are combinations of the above vowels and the nasal with each other or with laryngeal [h], like [əm], [əh], [əmh], $[\mathrm{h} ə \mathrm{~h}],[\varepsilon \mathrm{ch}]$.

We have analyzed the proportion of filled pause forms in the corpus. A schwa-like vowel is the most frequently pronounced form observed with Hungarian speakers. $78.5 \%$ of all filled pauses in the narratives were such sounds (Figure 3). Speakers produce the bilabial nasal in $10.9 \%$ and [əm] in $7.6 \%$ of all filled pauses. The proportion of other forms ([əm], [əh], [əmh], etc.) taken together is $3 \%$. The occurrence of the various filled pause forms was not speaker-dependent.

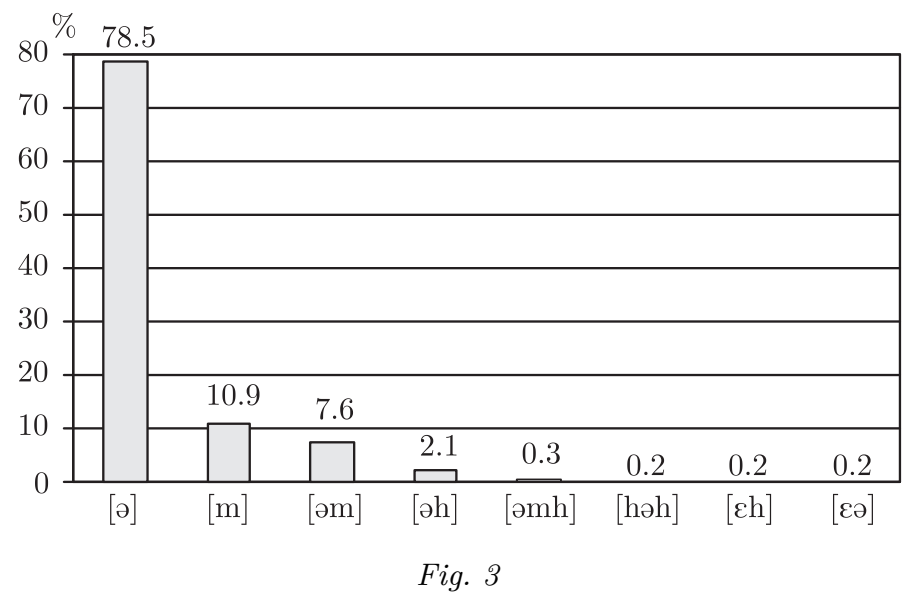

The occurrence of the types of filled pauses

Forms containing more than one speech sound generally require more complex articulatory planning than those consisting of a single speech sound (depending also on the degree of familiarity of the form and on its frequency of occurrence). Although it cannot be proved that the complex forms of filled pauses are results of intended articulation gestures on the part of the speaker, we might assume that the production of these complex sound sequences (i) requires more attention than performing simple articulation gestures and (ii) might involve various operations at 
the speech planning levels before execution. Therefore complex sound sequences are less suitable than filled pause forms consisting of single speech sounds for resolving speech planning problems.

Filled pauses occurred together with silent pauses in $75.6 \%$ of all cases. These silent pauses either preceded or followed filled pauses or they occurred in both positions. The combination of filled pauses and silent pauses can be divided into three categories according to the place of the silent pause: (i) a silent pause both precedes and follows a filled pause, (ii) a silent pause precedes a filled pause, or (iii) a silent pause follows a filled pause. Figure 4 shows the occurrences of these combinations as well as the occurrence of filled pauses without any silent pause.

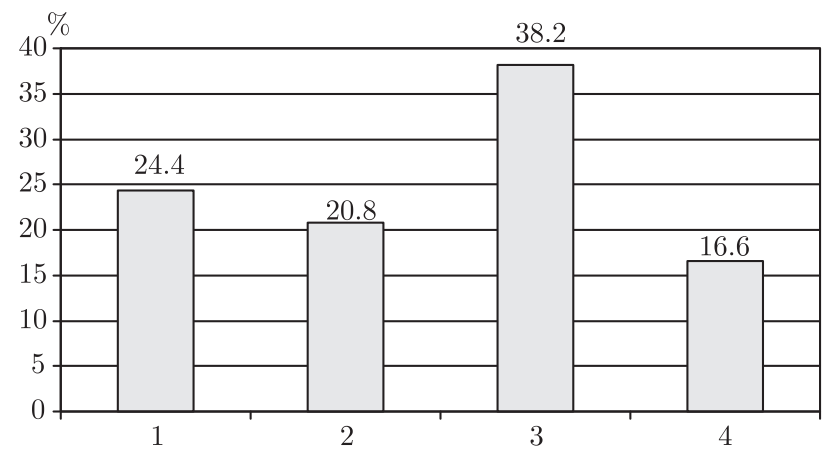

Fig. 4

The occurrences of silent pauses in the vicinity of filled pauses

( $1=$ no silent pause; $2=$ silent pause preceding filled pause;

$3=$ silent pause following filled pause; $4=$ silent pause both preceding and following filled pause)

The most frequent combination of silent pause and filled pause was when the silent pause followed the filled pause (38.2\% of all occurrences). This combination can be explained by the necessity of more time for the solution of the speech planning problem of the speaker or his/her intention for correction. In other words, if a filled pause has not provided enough time for the speaker, s/he seeks another possibility to gain time for executing his/her speech planning successfully. In these cases the simplest possibility is to remain silent for some time. In example (1), the speaker is probably trying to find the appropriate grammatical form or the appropriate word for his/her thought (cf. Fig. 5). A relatively long silent pause follows a relatively short filled pause, suggesting that the speaker has a planning problem for which s/he is trying to find the solution. (In the examples, 'öö' stands for [ə] and ' $\square$ ' stands for a silent pause.) 
(1) nem ö̈̈ $\square$ nem túl gyakran keresett

'not $\ddot{0} \ddot{0} \square$ not too often has he been looking for me'

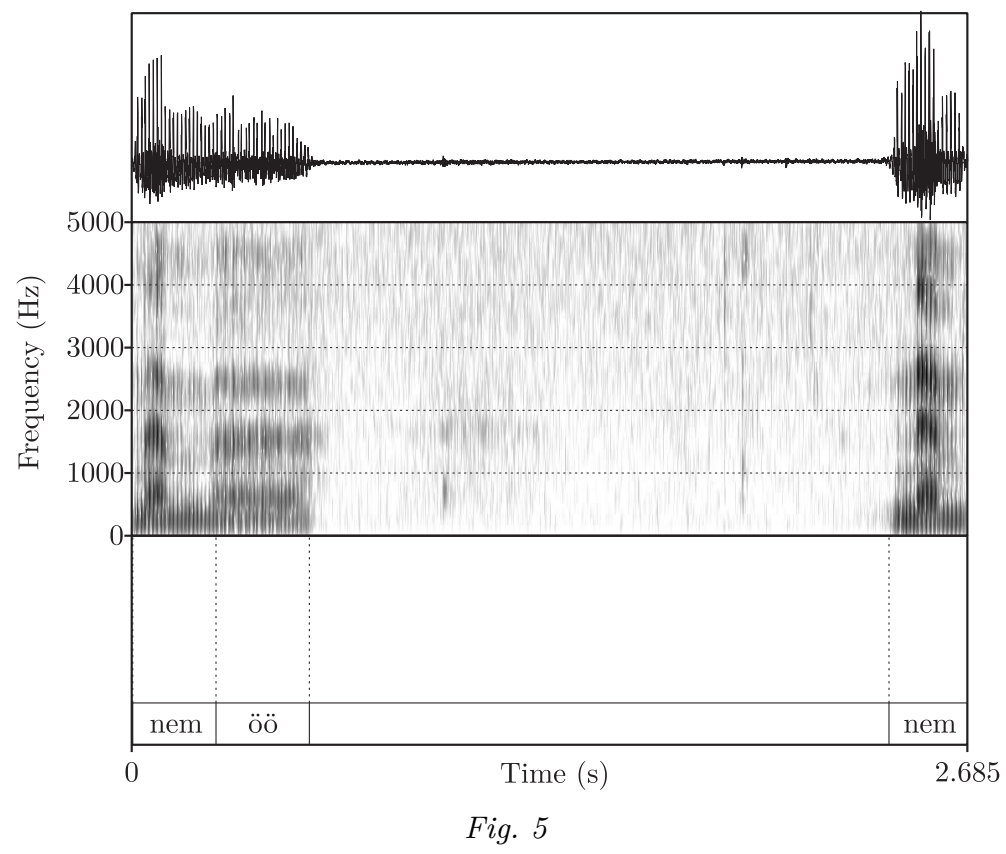

Silent pause following filled pause in the utterance nem $\ddot{\boldsymbol{o}} \ddot{\text { nem }} \square$

In example (2), a filled pause is both preceded and followed by a silent pause. This strategy could be observed in $16.6 \%$ of all occurrences. We suppose that the speaker tries to find the solution for the planning problem during the first silent pause. Since he is unable to do so, the continuation is a filled pause that is closer to the speech flow in sounding than a silent pause is. However, to solve the problem he needs extra time, so he suppresses vocalization again and after that he is able to continue speaking.

(2) mennyire befolyásolja a többit $\square$ öö $\square$ irodalomból Kosztolányi regényéről írok 'how does this influence the others $\square$ ö̈ $\square$ I write an essay about Kosztolányi's novel'

The duration of silent pause plus filled pause combinations was analyzed depending on their order. The mean duration of silent pauses preceding filled pauses is $599 \mathrm{~ms}$ while the mean duration of those following them is $498 \mathrm{~ms}$ (Table 1). Silent pauses preceding filled pauses are longer on 
average than those following them (one-way ANOVA: $F(1,610)=5.434$, $p=0.020)$.

Table 1

The duration of silent pauses in the vicinity of filled pauses (ms)

\begin{tabular}{lcc}
\hline & \multicolumn{2}{c}{ Duration of silent pauses (ms) } \\
\cline { 2 - 3 } & Preceding filled pause & Following filled pause \\
\hline mean & 599 & 498 \\
SD & 474 & 554 \\
min. & 30 & 22 \\
max. & 2671 & 3283 \\
\hline
\end{tabular}

We have analyzed the function of filled pauses in spontaneous speech on the basis of their syntactic-semantic contexts. Two main functions were determined and one of them was divided into two subtypes. One of the two main functions is marking the speaker's production problem while the other one indicates the speaker's intention to speak. This latter is called the phatic marker function (cf. Gósy-Horváth in press). A filled pause marking the speaker's production problem can refer either to an internal planning problem when the error itself does not appear on the surface or to an error that appears on the surface. In the first case, the filled pause marks an internal production problem occurring at any level of planning while in the second case the internal planning problem appears as a surface error that is accompanied by a filled pause. When there is no error on the surface, the nature of the internal planning disharmony is hard to define. Filled pauses of this kind will be identified as marks of internal planning problems. A surface error is a more exact mark of the nature of the internal planning disharmony at hand. Filled pauses used in a phatic marker function are produced to introduce a new part of the utterance, or in cases where the speaker tries to expand the message by means of a more comprehensible form. This function overlaps with the function of discourse markers (Jucker 1993; Fox Tree-Schrock 2002). Examples (3)-(6) illustrate the functions of resolving internal planning problem by means of filled pauses.

(3) még a maradék élvezeti ööö érték is elveszne

'even the remaining pleasure ö̈̈̈ value would be lost' 
(4) nekem mondjuk ööö én mondjuk fel akarok használni 'for me, let's say ööö let's say I want to utilize'

(5) aki valami újat tesz... öm hát én sem voltam valami jó gyerek 'who does something new öm well I wasn't a well-behaved child either'

(6) nem köt le tehát öö nekem egy blöff a főiskola 'I'm not interested so öö for me, college is a bluff'

Examples (7)-(8) show the same function. In utterance (7), the speaker is looking for the word hirdetések 'commercials' and this difficult lexical access results in a filled pause $\mathbf{m m m}$ on the surface. Before being successful in finding the right word the speaker utters a word of similar meaning saying that it is not the one he was looking for (nem információk 'not information'). There is an error of the anticipation type in example (8). The fragment ha... comes from hallani 'to hear' - it was pronounced earlier than the speaker had intended. As a result of self-monitoring, the speaker recognized the problem and articulation was interrupted according to the main interruption rule- "stop the flow of speech immediately upon detecting trouble" (Levelt 1989, 478). The speaker marked his problem by a filled pause, and the repair of the utterance was also done during filled pause.

(7) jön le a tévéből ezek a közérdekü mmm nem információk, hanem hirdetésekből 'coming from the TV from these public mmm not information but commercials'

(8) és ha... öö mást sem lehetett hallani a tévében 'and her... öö nothing else could be heard from the TV'

Speakers often use complex forms to indicate their intention to speak because of the longer durations of such forms. Example (9) contains an utterance initial filled pause marking that the speaker starts speaking.

(9) öö én úgy általában nem nagyon szoktam inni ‘öö I usually don't drink too much'

Filled pauses revealing internal planning problems occurred in our material in $86.9 \%$ of all filled pauses while those accompanying a surface speech error occurred in $6.8 \%$ of all cases. The phatic marker function (marking intention to speak) occurred in $6.3 \%$ of all filled pauses (Figure 6). 


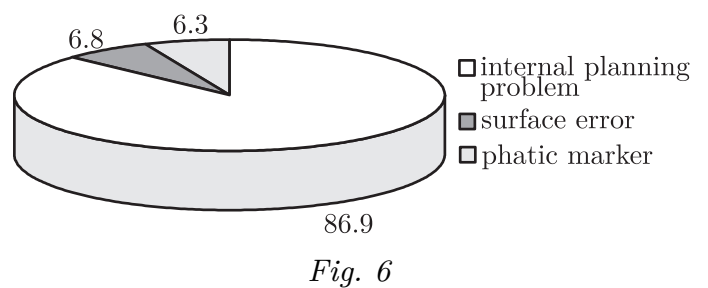

The percentage of the main functions of filled pauses

The question of interrelations between the functions and the phonetic forms of filled pauses was also analyzed. The three types of function defined earlier were (i) marking the speaker's production problem during speech planning that is manifested in a filled pause on the surface, (ii) marking the speaker's production problem that is manifested both in a filled pause and in some error and (iii) indicating the speaker's intention to speak. The question is whether the most frequent phonetic forms of filled pause can be related to various functions. Although there are no large differences in phonetic forms depending on function, there are clear tendencies indicating important functional differences. The schwalike filled pause occurs in the majority of cases in all functions; however, their ratio is lower in the phatic function than in the other two functions (Figure 7).

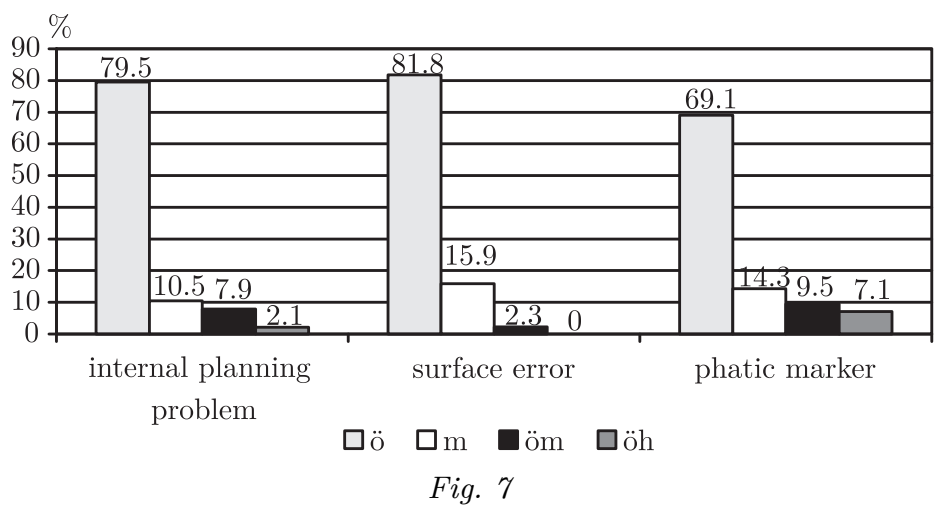

The occurrence of the most frequent filled pause forms depending on function

Filled pauses consisting of a single speech sound other than schwa are characteristic of the function of marking a speech planning problem to a larger extent than in the other cases. This means that the ratio of the most frequent complex forms is higher in cases of the phatic function $(16.6 \%$ 
as opposed to $10.0 \%$ and $2.3 \%$ ). A cautious conclusion can be drawn that the complex forms of filled pause are not as effective as the singlesound forms. Since these complex forms require complicated organization of articulation gestures, speakers seem to avoid using them when having speech planning difficulties.

We have investigated whether the function of the schwa-like vowel affects its duration. Speakers produce this vowel with an average duration of $303 \mathrm{~ms}$ (SD: 146) in cases of an internal planning problem, and with $370 \mathrm{~ms}$ (SD: 173) in the phatic marker function. Statistical analysis showed significant differences in duration depending on functions. The data supported the assumption of function-dependent temporal characteristics of filled pauses. The articulation of this vowel in the phatic marker function was completed in a longer time than in the case of an internal planning problem $(t(483)=-2.368 ; p=0.018)$. Expressing intention to speak is a more conscious act than expressing difficulties in speech planning; this distinction results in differences in duration. The schwa-like vowel was produced with an average duration of $314 \mathrm{~ms}$ (SD: $220)$ in the vicinity of speech errors. There were no significant differences between the durations of schwa-like vowels in this function and the two other functions (Figure 8).

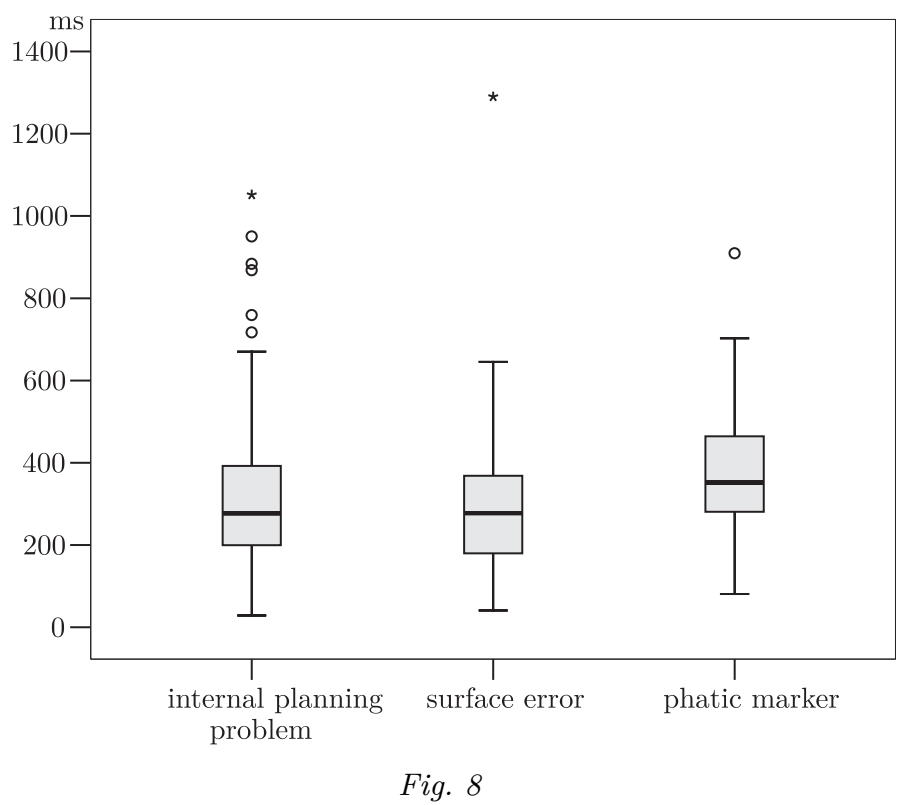

Duration of schwa-like filled pauses depending on function 
Statistical analysis could not be performed on filled pauses involving [m] because of the low number of occurrences in each function. The mean values showed, however, that the bilabial nasal in the case of an internal planning problem was completed in a shorter time than in the phatic marker function (Table 2).

Table 2

Duration of nasal depending on function (means and standard deviations)

\begin{tabular}{lcc}
\hline & \multicolumn{2}{c}{ Duration of $m$ depending on function $(\mathrm{ms})$} \\
\cline { 2 - 3 } Function & Mean & SD \\
\hline Internal planning problem & 268 & 234 \\
Surface error & 395 & 299 \\
Phatic marker & 426 & 373 \\
\hline
\end{tabular}

$\ddot{O} m[ə \mathrm{~m}]$ occurred together with a speech error just once, its duration in this case was $279 \mathrm{~ms}$. In contrast to schwa-like and nasal filled pauses, speakers produced the form $\ddot{o} m$ with a shorter duration in the phatic marker function than in the case of an internal planning problem (Table 3).

Table 3

Duration of $\ddot{o} m$ depending on function (means and standard deviations)

\begin{tabular}{lcc}
\hline & \multicolumn{2}{c}{ Duration of öm depending on function (ms) } \\
\cline { 2 - 3 } Function & Mean & SD \\
\hline Internal planning problem & 487 & 262 \\
Phatic marker & 262 & 116 \\
\hline
\end{tabular}

The filled pause $\ddot{o} h$ [əh] occurred only in the internal planning problem and phatic marker functions, just like öm. According to the data, speakers produced $\ddot{o} h$ forms, too, with a shorter duration in the case of planning problems than in the phatic marker function (Table 4). We could see that the duration of filled pauses is longer in the phatic marker function than in any other function (like error marking). The data revealed that the largest difference in duration depending on functions was found with $\ddot{o} h$. 
Table 4

Duration of $\ddot{o h}$ depending on function (means and standard deviations)

\begin{tabular}{lcc}
\hline & \multicolumn{2}{c}{ Duration of öh depending on function (ms) } \\
\cline { 2 - 3 } Function & Mean & SD \\
\hline Internal planning problem & 544 & 172 \\
Phatic marker & 805 & 115 \\
\hline
\end{tabular}

The frequency values of the first two formants of the schwa-like realizations were also analyzed. The aim of the analysis was to determine whether or not the values of F1 and F2 depend on the function of the schwa-like vowel. The first formant of the schwa was the same in all functions (without any significant differences; see Table 5 for the values). This means that tongue height does not vary across functions.

Table 5

$\mathrm{F} 1$ values of realizations of [ə] depending on function $(\mathrm{Hz})$ (means and standard deviations, SD)

\begin{tabular}{lcccccccc}
\hline & \multicolumn{2}{c}{ Internal planning problem } & & \multicolumn{2}{c}{ Surface error } & & \multicolumn{2}{c}{ Phatic marker } \\
\cline { 2 - 3 } Function & mean & SD & & Mean & SD & & Mean & SD \\
\hline Males & 446 & 51 & & 447 & 68 & & 459 & 43 \\
Females & 504 & 73 & & 472 & 83 & & 508 & 78 \\
\hline
\end{tabular}

The second formant values seem to be indicators of the function-dependent realization of the schwa-like sound since they show clear differences depending upon function (Table 6, overleaf); however, the difference is significant only in males' articulation. The F2 value of schwa-realizations is higher in the case of internal planning problems than in the phatic marker function $(t(236)=-2.594 ; p=0.016)$. Function-dependent realization correlates with the horizontal movement of the tongue. There were no such significant differences in F2 values of [ə] when it occurred together with surface errors and in the two other functions.

There were no significant differences in the F2-values depending on function in the females' articulation; however, in their case, there was a tendency of highest second formant values in the phatic function. 
Table 6

F2 values of realizations of [ə] depending on function $(\mathrm{Hz})$ (means and standard deviations, SD)

\begin{tabular}{lcccccccc}
\hline & \multicolumn{2}{c}{ Internal planning problem } & & \multicolumn{2}{c}{ Surface error } & & \multicolumn{2}{c}{ Phatic marker } \\
\cline { 2 - 3 } Function & mean & SD & & Mean & SD & & Mean & SD \\
\hline Males & 1550 & 139 & & 1522 & 154 & & 1481 & 108 \\
Females & 1770 & 138 & & 1726 & 189 & & 1782 & 238 \\
\hline
\end{tabular}

\section{Conclusions}

Filled pauses show several kinds of realizations in Hungarian. The most frequent forms are schwa-like sounds; speakers produce them close to $80 \%$ of all cases. Speakers prefer the schwa-like sound because of its neutral and simple articulation. However, there are filled pauses containing two or more speech sounds which are used successfully for marking the speaker's intention to speak. We might conclude that there is a tendency of function division among the filled pause forms.

Silent pauses can occur in the vicinity of filled pauses. Silent pauses following filled pauses are more frequent than those preceding them. However, silent pauses that precede filled pauses are longer (by $100 \mathrm{~ms}$ on average) than those following them because speakers make an effort to manage planning or error correction during the first silent pause. If this process is not successful, the speaker has to use another type of disfluency to solve the problem: in our case, this is where filled pause comes into the picture.

Filled pauses have several functions in spontaneous speech. They provide time for speech planning processes and self-repair, they also mark the speaker's intention to speak. The majority of all filled pauses (86.9\%) were produced because of the speakers' internal planning problems or their trials to overcome them. $6.8 \%$ of all filled pauses occurred together with a surface speech error while $6.3 \%$ of them served the phatic marker function.

The most frequent form, a schwa-like vowel, shows function-dependent variability in duration. Speakers produce it with a longer duration to mark their intention to speak as opposed to cases when they indicate some planning problem. The values of the first formant showed no change 
across functions. The values of the second formant, however, show differences depending upon function in males' but not in females' articulation. The value of $\mathrm{F} 2$ is higher in the case of an internal planning problem than in the phatic marker function with the male subjects. These results might refer to the speakers' inclination to alter their articulation in terms of function.

The more we learn about the acoustic-phonetic characteristics of filled pauses (on the surface) the better assumptions on internal planning processes can be defined.

\section{References}

Beattie, Geoffrey W.-Brian L. Butterwoth 1979. Contextual probability and word frequency as determinants of pauses and errors in spontaneous speech. In: Language and Speech $22: 201-11$.

Boersma, Paul-David Weenink 2005. Praat: Doing phonetics by computer. (Version 4.5) [Computer program]. http://www.praat.org/

Bóna, Judit 2006. A megakadásjelenségek akusztikai és percepciós sajátosságai [Acoustic and perceptual properties of disfluency phenomena]. In: Mária Gósy (ed.): Beszédkutatás 2006 [Speech research 2006], 101-13. MTA Nyelvtudományi Intézet, Kempelen Farkas Beszédkutató Laboratórium, Budapest.

Bortfeld, Heather-Silvia D. Leon - Jonathan E. Bloom-Michael F. Schober-Susan E. Brennan 2001. Disfluency rates in conversations: Effects of age, relationship, topic, role and gender. In: Language and Speech $44: 123-47$.

Boulton, Alex 2006. To er is human: Silent pauses and speech dysfunctions of the 2004 US presidential debates. In: Myriam Pereiro-Henry Daniels (eds): Le désaccord, 7-32. AMAES, Nancy.

Brennan, Susan E.-Maurice Williams 1995. The feeling of another's knowing: Prosody and filled pauses as cues to listeners about the metacognitive states of speakers. In: Journal of Memory and Language $34: 383-98$.

Bunnel, H. Timothy-William Idsardi (eds) 1996. Proceedings of the Fourth International Congress on Spoken Language Processing. Institute of Electrical \& Electronics Engineers, Philadelphia.

Clark, Herbert H. 1994. Managing problems in speaking. In: Speech Communication $15: 243-50$.

Clark, Herbert H. - Jean E. Fox Tree 2002. Using uh and um in spontaneous speaking. In: Cognition 84:73-111.

Cook, Mark 1971. The incidence of filled pauses in relation to part of speech. In: Language and Speech 14:135-9.

Corley, Martin-Robert J. Hartsuiker 2003. Hesitation in speech can... um... help a listener understand. In: Richard Alterman-David Hirsch (eds): Proceedings of the Twenty-fifth Annual Conference of the Cognitive Science Society, 276-81. Erlbaum, Mahwah NJ.

Acta Linguistica Hungarica 57, 2010 
Corley, Martin-Oliver W. Stewart 2008. Hesitation disfluencies in spontaneous speech: The meaning of um. In: Language and Linguistics Compass 4:589-602.

Duez, Danielle 1982. Silent and non-silent pauses in three speech styles. In: Language and Speech $25: 11-28$.

Eklund, Robert 2001. Prolongations: A dark horse in the disfluency stable. In: Proceedings of ISCA Tutorial and Research Workshop on Disfluency in Spontaneous Speech (DiSS'01), 5-8. University of Edinburgh, Edinburgh.

Fox Tree, Jean E. 2002. Interpreting pauses and ums at turn exchanges. In: Discourse Process $34: 37-55$.

Fox Tree, Jean E.- Josef C. Schrock 2002. Basic meanings of you know and I mean. In: Journal of Pragmatics $34: 727-47$.

Fromkin, Victoria A. 1973. The non-anomalous nature of anomalous utterances. In: Victoria A. Fromkin (ed.): Speech errors as linguistic evidence, 215-42. Mouton, The Hague.

Goldman-Eisler, Frieda 1958. Speech analysis and mental processe. In: Language and Speech 1:59-75.

Gósy, Mária 2000. A beszédszünetek kettős funkciója [The double function of pauses in speech]. In: Mária Gósy (ed.): Beszédkutatás 2000 [Speech research 2000], 1-14. MTA Nyelvtudományi Intézet, Budapest.

Gósy, Mária 2002. A megakadásjelenségek eredete a spontán beszéd tervezési folyamatában [The origin of disfluencies in planning process of spontaneous speech]. In: Magyar Nyelvőr $126: 192-204$.

Gósy, Mária 2003. A spontán beszédben előforduló megakadásjelenségek gyakorisága és összefüggései [The frequency and interrelations of disfluencies in spontaneous speech]. In: Magyar Nyelvőr $127: 257-77$.

Gósy, Mária (ed.) 2004. Beszédkutatás 2004 [Speech research 2004]. MTA Nyelvtudományi Intézet, Budapest.

Gósy, Mária 2008. Magyar spontánbeszéd-adatbázis - BEA [Hungarian spontaneous speech corpus - BEA]. In: Mária Gósy (ed.): Beszédkutatás 2008 [Speech research 2008], 194-207. MTA Nyelvtudományi Intézet, Kempelen Farkas Beszédkutató Laboratórium, Budapest.

Gósy, Mária-Viktória Horváth in press. Changes in articulation accompanying functional changes in word usage. In: Journal of the International Phonetic Association.

Hokkanen, Tapio 2001. Slips of the tongue. Errors, repairs and a model. Finnish Literature Society, Helsinki.

Horváth, Viktória 2004. Megakadásjelenségek a párbeszédekben [Disfluencies in dialogues]. In: Gósy (2004, 187-99).187-199.

House, David 2003. Hesitation and interrogative Swedish intonation. http://www.ling.umu.se/fonetik2003/

Jucker, Andreas H. 1993. The discourse marker well: A relevance-theoretical account. In: Journal of Pragmatics 19:435-52.

Lallgee, Mansur G.-Mark Cook 1969. An experimental investigation of the function of filled pauses in speech. In: Language and Speech $12: 2428$. 
Levelt, Willem. J. M. 1989. Speaking: From intention to articulation. MIT Press, Cambridge MA.

Lickley, Robin J. 1995. Missing disfluencies. In: Kjell Elenius-Peter Branderud (eds): Proceedings of the Thirteenth International Congress of Phonetic Sciences, Vol. 4, 192-5. University of Stockholm, Stockholm.

Lickley, Robin J.-Ellen Gurman Bard 1996. On not recognising disfluencies in dialogue. In: Bunnel-Idsardi (1996, 1876-9).

Livant, William Paul 1963. Antagonistic funczions of verbal pauses: Filled and unfilled pauses in speech. In: Language and Speech $6: 1-4$.

Local, John 2004. Getting back to prior talk: and-uh(m) as a back-connecting device. In: Elizabeth Couper-Kuhlen-Cecilia E. Ford (eds): Sound production in interaction, 377-400. John Benjamins, Amsterdam \& Philadelphia.

Maclay, Howard-Charles E. Osgood 1959. Hesitation phenomena in spontaneous English speech. In: Word $15: 19-44$.

Mahl, George F. 1956. Disturbances and silences in the patient's speech in psychotherapy. In: Journal of Abnormal and Social Psychology 53:1-15.

Markó, Alexandra 2004. Megakadások vizsgálata különféle monologikus szövegekben [The analysis of disfluencies in various narratives]. In: Gósy (2004, 209-22).

Merlo, Sandra-Leticia Lessa Mansur 2004. Descriptive discourse: Topic familiarity and disfluencies. In: Journal of Communication Disorders 37:489-503.

Ruder, Kenneth F.-Paul J. Jensen 1972. Fluent and hesitation pauses as a function of syntactic complexity. In: Journal of Speech and Hearing Research 15:49-60.

Shriberg, Elizabeth 1996. Disfluencies in switchboard. In: Bunnel-Idsardi (1996, Addendum, 11-4).

Shriberg, Elizabeth 2001. To 'errrr' is human: Ecology and acoustics of speech disfluencies. In: Journal of the International Phonetic Association 31:153-169.

Watanabe, Michiko - Keikichi Hirose - Yasuharu Den - Nobuaki Minematsu 2008. Filled pauses as cues to the complexity of upcoming phrases for native and non-native listeners. In: Speech Communication 50 : 81-94.

Yaruss, J. Scott-Robyn M. Newman-Tracy Flora 1999. Language and disfluency in nonstuttering children's conversational speech. In: Journal of Fluency Disorders $24: 185-207$. 